Percorrere il solco di itinerari già tracciati dai protagonisti del dibattito architettonico italiano è azione colta e proattiva. La sintesi derivante dai fattori artistico-umanistici unitamente alla componente tecnico-scientifica rappresenta la radice del processo che plasma larchitetto come figura intellettuale in grado di governare processi materiali connessi all'idoneità di saper selezionare sapientemente tempi, fasi e attori: elementi, questi, affiancati da quella magica ed essenziale sensibilità compositiva che, sin dalle origini, alimenta tale mestiere.

Latto di radiografare il ruolo dellarchitettura per mezzo del filtro dell'"autonomia" o dell'"eteronomia" della medesima, in tempi di ibridazione delle conoscenze e compenetrazioni disciplinari, facilita la comprensione delle tendenze in atto, favorendo lattualizzazione di frammenti di un dibattito scolpiti nella nostra cultura e tradizione.

Eteronomia, perciò, quale condizione nella quale un soggetto agente riceve da fuori di sé la norma della propria azione: la matrice del suo significato, proveniente dal greco antico, che vede la fusione di due termini ě̃ nómos "legge, governo", restituisce l'anima di un duplice sentimento che oggi pervade l'architettura: il peccato dell'autoreferenzialità e la forza della dipendenza da altri saperi.

La differenza eletta a valore e la capacità di instaurare relazioni tra punti di osservazione differenti, divengono momenti di una prassi di valorizzazione del processo e del metodo di affermazione dell'architettura quale disciplina.

Il termine "eteronomia", usato in contrapposizione ad "autonomia", da Kant in poi ha assunto un valore positivo connesso al reciproco rispetto tra ragione e creatività, tra scienza esatta e approccio empirico, tra contaminazione e isolamento, introducendo ogni qual volta il valore sociale della sua esistenza.

\section{THE ARCHITECTURE OF DIFFERENCES}

Following in the footsteps of the protagonists of the Italian architectural debate is a mark of culture and proactivity. The synthesis deriving from the artistic-humanistic factors, combined with the technical-scientific component, comprises the very root of the process that moulds the architect as an intellectual figure capable of governing material processes in conjunction with their ability to know how to skilfully select schedules, phases and actors: these are elements that - when paired with that magical and essential compositional sensitivity - have fuelled this profession since its origins.

The act of X-raying the role of architecture through the filter of its "autonomy" or "heteronomy", at a time when the hybridisation of different areas of knowledge and disciplinary interpenetration is rife, facilitates an understanding of current trends, allowing

Nella conferenza di Lima del 1949, Ernesto Nathan Rogers affiancava al principio dell'“Architettura è un'Arte" le istanze di una dimensione sociale della medesima: «L'Alberti, nella estrema precisione del suo pensiero, ci ammonisce che l'idea deve essere tradotta in opere e che queste debbono avere un fine pratico e morale per adattarsi armonicamente "allo uso delli uomini" e vorrei far notare il plurale di "uomini", società. Larchitetto non è un prodotto passivo né un creatore completamente indipendente dalla propria epoca: la società è il materiale grezzo ch'egli trasforma conferendogli un aspetto, un'espressione, e la coscienza di quegli ideali che senza di lui rimarrebbero impliciti. La nostra profezia, come quella dell'agricoltore, contiene già le sementi di crescite future, poiché anche la nostra opera sta tra il cielo e la terra. La poesia, la pittura, la scultura, la danza e la musica, anche quando esprimono l'attualità, non sono necessariamente limitate entro termini pratici. Ma noialtri architetti, che abbiamo come compito la sintesi tra l'utile e la bellezza, dobbiamo sentire in ogni momento creativo il dramma fondamentale dell'esistenza perché la vita pone continuamente in contraddizione i bisogni pratici e le aspirazioni spirituali. Noi non possiamo rigettare né l'una né l'altra di queste necessità perché una posizione meramente pratica o moralistica nega il valore pieno dell'architettura altrettanto quanto lo farebbe una posizione puramente estetica: dobbiamo mediare una posizione nell'altra» (Rogers, 1948).

Rogers disquisisce sulla relazione tra forze istintive e conoscenze acquisite per mezzo della cultura, unitamente al pensiero su quale sia il ruolo dello studio nella formazione di un artista. É in taluni dibattiti sorti all'interno dei "Congressi Internazionali di Architettura Moderna" che il tema dell'architettura, come disciplina collocata tra autosufficienza e dipendenza, acquisisce

us to bring the fragments of a debate carved into our culture and tradition up to date.

As such, heteronomy - as a condition in which an acting subject receives the norm of its action from outside itself: the matrix of its meaning, coming from ancient Greek, the result of the

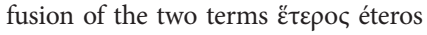
"different, other" and vónoc nómos "law, ordinance" - suggests the existence of a dual sentiment now pervasive in architecture: the sin of self-reference and the strength of depending on other fields of knowledge.

Difference, interpreted as a value, and the ability to establish relationships between different points of observation become moments of a practice that values the process and method of affirming architecture as a discipline.

The term "heteronomy", used in opposition to "autonomy", has - from the time of Kant onwards - taken on a positive value connected to the mutual respect between reason and creativity, exact science and empirical approach, contamination and isolation, introducing the social value of its existence every time that it returns to the forefront.

At the 1949 conference in Lima, Ernesto Nathan Rogers spoke on combining the principle of "Architecture is an Art" with the demands of a social dimension of architecture: «Alberti, in the extreme precision of his thought, admonishes us that the idea must be translated into works and that these must have a practical and moral purpose in order to adapt harmoniously 'to the use of men', and I would like to point out the use of the plural of 'men', society. The architect is neither a passive product nor a creator completely independent of his era: society is the 


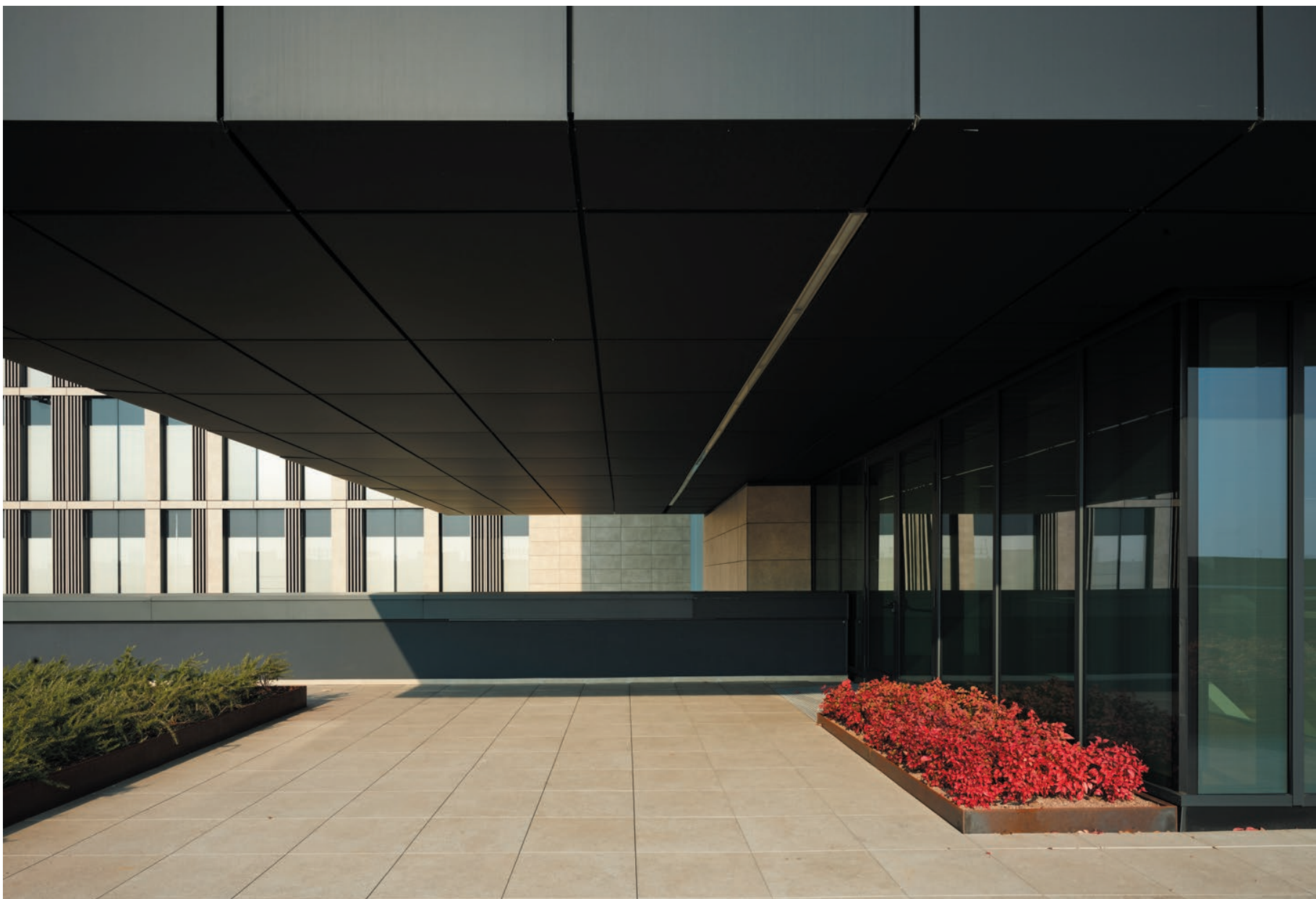

raw material that he transforms, giving it an appearance, an expression, and the consciousness of those ideals that, without him, would remain implicit. Our prophecy, like that of the farmer, already contains the seeds for future growth, as our work also exists between heaven and earth. Poetry, painting, sculpture, dance and music, even when expressing the contemporary, are not necessarily limited within practical terms. But we architects, who have the task of synthesising the useful with the beautiful, must feel the fundamental drama of existence at every moment of our creative process, because life continually puts practical needs and spiritual aspirations at odds with one another. We cannot reject either of these necessities, because a merely practical or moralistic position denies the full value of architecture to the same extent that a purely aesthetic position would: we must mediate one position with the other» (Rogers, 1948).

Rogers discusses at length the relationship between instinctive forces and knowledge acquired through culture, along with his thoughts on the role played by study in an artist's training. It is in certain debates that have arisen within the "International Congresses of Modern Architecture" that the topic of architecture as a discipline caught between self-sufficiency and dependence acquires a certain centrality within the architectural context: in particular, in this scenario, the theme of the "autonomy" and "heteronomy" of pre-existing features of the environment plays a role of strategic importance. Arguments regarding the meaning of form in architecture and the need for liberation from heteronomous influences did not succeed in undermining the idea of an architec- ture capable of influencing the governing of society as a whole, thanks to an attitude very much in line with Rogers' own writings.

The idea of a project as the result of the fusion of an artistic idea and preexisting features of an environment formed the translation of the push to coagulate the antithetical forces striving for a reading of the architectural work that was at once autonomous and heteronomous, as well as linked to geographical, cultural, sociological and psychological principles.

The CIAM meeting in Otterlo was attended by Ignazio Gardella, Ernesto Nathan Rogers, Vico Magistretti and Giancarlo De Carlo as members of the Italian contingent: the architects brought one project each to share with the conference and comment on as a manifesto. Ernesto Nathan Rogers, who presented the Velasca Tower, and
Giancarlo De Carlo, who presented a house in Matera in the Spine Bianche neighbourhood, were openly criticised as none of the principles established by the CIAM were recognisable in their work any longer, and De Carlo's project represented a marked divergence from a consolidated method of designing and building in Matera.

In this cultural condition, Giancarlo De Carlo - in justifying the choices he had made - even went so far as to say: «my position was not at all a flight from architecture, for example in sociology. I cannot stand those who, paraphrasing what I have said, dress up as politicians or sociologists because they are incapable of creating architecture. Architecture is - and cannot be anything other than - the organisation and form of physical space. It is not autonomous, it is heteronomous» (De Carlo, 2001). 
centralità all'interno del contesto architettonico: in particolare, in tale scenario, il tema dell'"autonomia" ed "eteronomia" delle preesistenze ambientali riveste un ruolo di evidenza strategica. I ragionamenti inerenti al significato della forma in architettura e l'esigenza di liberarsi da influenze eteronome, non sono riuscite a indebolire l'idea di un'architettura capace di influire nel governo dell'intera società, grazie ad un atteggiamento molto affine agli scritti di Rogers medesimo.

Il pensiero di un progetto quale risultato della fusione tra idea artistica e preesistenze ambientali traduceva l'istanza di coagulare le antitetiche forze tendenti a una lettura, al contempo, autonoma ed eteronoma dell'opera architettonica, connessa altresì ai principi geografici, culturali, sociologici, psicologici.

Alla riunione dei CIAM di Otterlo parteciparono, come componenti del gruppo italiano, Ignazio Gardella, Ernesto Nathan Rogers, Vico Magistretti, Giancarlo De Carlo: gli architetti portarono un progetto a testa da condividere e commentare come manifesto. Ernesto Nathan Rogers, che esibì la Torre Velasca, e Giancarlo De Carlo, che mostrò una casa a Matera nel quartiere Spine Bianche, furono apertamente criticati in quanto nelle loro opere non pareva più riconoscersi alcun principio sancito dai CIAM, e il progetto di De Carlo identificava la rottura con un consolidato metodo di progettare e realizzare a Matera.

In tale condizione culturale Giancarlo De Carlo, al fine di motivare le scelte effettuate, giunse ad affermare: «la mia posizione non era affatto fuga dallarchitettura, per esempio nella sociologia. Io non posso sopportare quelli che, parafrasando quello che ho detto, si vestono da politici o da sociologi perché sono incapaci di fare architettura. Larchitettura è - e non può essere

Even more so than in the past, it is not possible today to imagine an architecture encapsulated entirely within its own enclosure, autoimmune, averse to any contamination or relationships with other disciplinary worlds: architecture is the world and the world is the sum total of our knowledge.

Architecture triggers reactions and phenomena: it is not solely and exclusively the active and passive product of a material work created by man. «We believed in the heteronomy of architecture, in its necessary dependence on the circumstances that produce it, in its intrinsic need to exist in harmony with history, with the happenings and expectations of individuals and social groups, with the arcane rhythms of nature. We denied that the purpose of architecture was to produce objects, and we argued that its fundamental role was to trigger processes of trans- formation of the physical environment that are capable of contributing to the improvement of the human condition» (De Carlo, 2001).

Productive and cultural reinterpretations place the discipline of architecture firmly at the centre of the critical reconsideration of places for living and working. Consequently, new interpretative models continue to emerge which often highlight the instability of built architecture with the lack of a robust theoretical apparatus, demanding the sort of "technical rationality" capable of restoring the centrality of the act of construction, through the contribution of actions whose origins lie precisely in other subject areas.

Indeed, the transformation of the practice of construction has resulted in direct changes to the structure of the nature of the knowledge of it, to the role of competencies, to the definition

altro che - organizzazione e forma dello spazio fisico. Non è autonoma, è eteronoma» (De Carlo, 2001).

Ancor più che in passato, non è possibile oggi pensare a una architettura rinchiusa nel proprio recinto, autoimmune, avversa a contaminazioni e relazioni con altri mondi disciplinari: l'architettura è il mondo e il mondo è l'insieme delle nostre conoscenze. Larchitettura scatena reazioni e fenomeni: non è solo ed esclusivamente esito attivo e passivo di un lavoro materiale dell'uomo. «Noi credevamo nell'eteronomia dell'architettura, nella sua necessaria dipendenza dalle circostanze che la producono, nel suo intrinseco bisogno di essere in sintonia con la storia, con le vicende e le aspettative degli individui e dei gruppi sociali, coi ritmi arcani della natura. Negavamo che lo scopo dell'architettura fosse di produrre oggetti e sostenevamo che il suo compito fondamentale fosse di accendere processi di trasformazione dell'ambiente fisico, capaci di contribuire al miglioramento della condizione umana» (De Carlo, 2001).

Le rivisitazioni produttive e culturali collocano la disciplina architettonica baricentrica alla riconsiderazione critica sui luoghi dell'abitare e del lavorare. Conseguentemente, emergono modelli interpretativi nuovi che spesso evidenziano la labilità dell'architettura costruita in mancanza di un robusto apparato teorico, reclamando quella "razionalità tecnica" in grado di ripristinare la centralità dell'atto costruttivo, per mezzo del contributo di azioni che, proprio da altre materie, hanno origine.

La trasformazione della pratica del costruire ha, infatti, implicato diretti cambiamenti alla struttura della natura del sapere, al ruolo delle competenze, alla definizione di nuove professionalità sulla base delle richieste emergenti dal sistema produttivo e socioculturale. Larchitetto non può ignorare che il fare dell'archi-

of new professional skills based on the demands emerging not just from the production system, but also from the socio-cultural system. The architect cannot disregard the fact that the making of architecture does not burn out by means of some implosive dynamic; rather, it is called upon to engage with the multiple facets and variations that the cognitive act of design itself implies, bringing into play a theory of disciplines which - to varying degrees and according to different logics - offer their significant contribution to the formation of the design and, ultimately, the work.

As Álvaro Siza claims, «The architect is not a specialist. The sheer breadth and variety of knowledge that practicing design encompasses today - its rapid evolution and progressive complexity - in no way allow for sufficient knowledge and mastery. Establishing connections - pro-jecting [from Latin proicere, 'to stretch out'] - is their domain, a place of compromise that is not tantamount to conformism, of navigation of the web of contradictions, the weight of the past and the weight of the doubts and alternatives of the future, aspects that explain the lack of a contemporary treatise on architecture. The architect works with specialists. The ability to chain things together, to cross bridges between fields of knowledge, to create beyond their respective borders, beyond the precarity of inventions, requires a specific education and stimulating conditions. [...] As such, architecture is risk, and risk requires impersonal desire and anonymity, starting with the merging of subjectivity and objectivity. In short, a gradual distancing from the ego. Architecture means compromise transformed into radical expression, in other words, a 
tettura non si esaurisce per mezzo di una dinamica implosiva, bensì è chiamato a confrontarsi con le molteplici declinazioni che l'atto cognitivo del progetto medesimo implica, chiamando in causa una teoria di discipline che, in misura e con logiche differenti, propongono il loro significativo contributo alla formazione del progetto e dell'opera.

Come afferma Alvaro Siza, "L'architetto non è uno specialista. La vastità e la varietà delle conoscenze che la pratica del progetto oggi comprende, la sua rapida evoluzione e progressiva complessità, in nessun modo permettono conoscenze e dominio sufficienti. Mettere in relazione - pro-gettando - è il suo dominio, luogo del compromesso che non significhi conformismo, della navigazione nell'intreccio delle contraddizioni, il peso del passato e il peso dei dubbi e delle alternative del futuro, aspetti che spiegano l'inesistenza di un trattato contemporaneo di architettura. Larchitetto lavora con specialisti. La capacità di concatenare, utilizzare ponti tra conoscenze, creare oltre le rispettive frontiere, oltre la precarietà delle invenzioni, esige un apprendimento specifico e condizioni stimolanti. [...] Perciò l'architettura è rischio, e il rischio richiede il desiderio impersonale e l'anonimato, a partire dalla fusione di soggettività e oggettività. In definitiva, il progressivo distanziamento dall'Io. Larchitettura significa compromesso trasformato in espressione radicale, cioè, capacità di assorbire l'opposto e di superare la contraddizione. Apprendere questo esige un in-segnamento alla ricerca dell'altro dentro di ognuno» (Siza, 2008).

$\mathrm{Si}$ assiste alla convivenza di tendenze progettuali contrastanti, spesso estreme, volte a riaffermare la matrice storica e tradizionale del costruire per mezzo della costante riproposizione dei caratteri di "persistenza" che l'architettura consolidata per sua

capacity to absorb the opposite and overcome contradiction. Learning this requires an education in search of the other within each of us» (Siza, 2008). We are seeing the coexistence of contrasting, often extreme, design trends aimed at recementing the historical and traditional mould of construction by means of the constant reproposal of the characteristics of "persistence" that long-established architecture, by its very nature, promotes, and at decrypting the evolutionary traits of architecture - markedly immaterial nowadays - that society promotes as phenomena of everyday living.

Speed, temporariness, resilience, flexibility: these are just a few fragments. In other words, we indicate a direction which immediately composes and anticipates innovation as a characterising element, describing its stylistic features, materials, languages and technologies, and only later on do we tend to outline the space that these produce: what emerges is a largely anomalous path that goes from "technique" to "function" - by way of "form" - denying the circularity of the three factors at play. The threat of a short-circuit deriving from discourse that exceeds action - in conjunction with a push for standardisation aimed at asserting the dominance of construction over architecture, once again echoing the ideas posited by Rogers - may yet be able to finding a lifeline cast through the attempt to merge figurative research with technology in a balanced way, in the wake of the still-relevant example of the Bauhaus or by emulating the thinking of certain masters of modern Italian architecture who worked during that post-war period so synonymous with physical - and, at the same time, moral - reconstruction. natura promuove, e a decriptare in architettura i lineamenti evolutivi, marcatamente immateriali oggi, che la società promuove quali fenomeni del vivere quotidiano.

Velocità, temporaneità, resilienza, flessibilità, sono solo taluni frammenti.

In altri termini, si denota una direzione a comporre e prefigurare da subito l'innovazione quale elemento caratterizzante, descrivendone, stilemi, materiali, linguaggi, tecnologie, e solo in un secondo momento si tende a delineare lo spazio che essi provocano: ne emerge un quantomeno anomalo tracciato che dalla "tecnica" giunge alla "funzione", per mezzo della "forma", negando la circolarità dei tre fattori in gioco.

La minaccia di un cortocircuito derivante da un disquisire che supera il fare, unitamente a unomologazione tesa al dominio dell'edilizia sull'architettura, riprendendo ancora il discorso "rogersiano", hanno la possibilità di trovare unàncora di salvataggio gettata attraverso il tentativo di fondere in modo equilibrato la ricerca figurativa con la tecnologia in scia al sempre attuale esempio del Bauhaus o emulando il pensiero di taluni maestri dell'architettura moderna italiana operanti in quel dopoguerra sinonimo di ricostruzione fisica e al contempo morale.

Lattitudine di questi ultimi alla trasformazione e all'adattamento formale e tecnico, rappresentano esempi paradigmatici di conforme scelta metodologica in riferimento all'elevato livello di dominio del processo progettuale e dello scandire delle sue fasi. Nell'esaltazione dell'esito, la forza del processo risulta spesso annebbiata: nell'acritica celebrazione dellopera architettonica il metodo sembra dissolversi nel prodotto compiuto.

L'innovazione tecnica e l'autoreferenzialità disciplinare sembrerebbero negare i concetti di continuità e trasversalità, per mezzo
These architectural giants' aptitude for technical and formal transformation and adaptation can be held up as paradigmatic examples of methodological choice consistent with their high level of mastery over the design process and the rhythm of its phases. In all this exaltation of the outcome, the power of the process is often left behind in a haze: in the uncritical celebration of the architectural work, the method seems to dissolve entirely into the finished product.

Technical innovation and disciplinary self-referentiality would seem to deny the concepts of continuity and transversality by means of a constant action of isolation and an insufficient relationship with itself: conversely, the act of designing, as an operation which involves selecting elements from a vast heritage of knowledge, cannot exempt itself from dealing in the variables of a functional, formal, material and linguistic nature - all of such closely intertwined intents - that have over time represented the energy of theoretical formulation and of the works created. For years, the debate in architecture has concentrated on the synergistic or contrasting dualism between cultural approaches linked to venustas and firmitas. Kenneth Frampton, with regard to the interpretative pair of "tectonics" and "form", notes the existence of a dual trend that is both identifiable and contrasting: namely the predisposition to favour the formal sphere as the predominant one, rejecting all implications on the construction, on the one hand; and the tendency to celebrate the constructive matrix as the generator of the morphological signature - emphasised by the ostentation of architectural detail, including that of a technological matrix - on the other. 
di una costante azione di isolamento e scarsità relazionale di sé stessa: al contrario, l'atto progettuale, in quanto operazione selettiva di un patrimonio vasto di conoscenze, non può esimersi dal trattare, in una comune unità d'intenti, le variabili di natura funzionale, formale, materica, linguistica che nel tempo hanno rappresentato l'energia della formulazione teorica e delle opere realizzate.

Per anni il dibattito in architettura si è concentrato sul dualismo sinergico o contrapposto tra approcci culturali legati alla venustas e alla firmitas. Kenneth Frampton, in merito alla coppia interpretativa "tettonica-forma", rileva l'esistenza di una duplice tendenza, identificabile e contrastante: la predisposizione a eleggere la sfera formale quale preponderante, respingendo ogni implicazione costruttiva, da un lato; il tendere a celebrare la matrice costruttiva quale generatrice della cifra morfologica, enfatizzata dallostentazione del dettaglio architettonico anche di matrice tecnologico, dall'altro.

Il progetto di architettura contemporaneo, si arricchisce di valenze tentacolari spesso fondamentali, a volte anche perniciose per la buona riuscita dell'opera: esso dovrebbe identificare il momento di coagulazione all'interno del quale il progettista persegue la ricerca d'equilibrio tra tutte le categorie interpretative che lo compongono, sposando l'accezione vitruviana, per la quale la pratica è «il continuo riflettere sull'utilità» e la teoria "consiste nel poter dimostrare e spiegare le cose fatte con la abilità tecnica secondo il principio della proporzione» (Vitruvio Pollione, 15 a.C.).

Larchitettura dovrà sempre più esibire il suo rappresentare un'attività applicata e intellettuale di mirata sintesi, di sistema complesso all'interno della quale è non solo auspicabile, bensì

The design of contemporary architecture is enriched with sprawling values that are often fundamental, yet at times even damaging to the successful completion of the work: it should identify the moment of coagulation within which the architect goes in pursuit of balance between all the interpretative categories that make it up, espousing the Vitruvian meaning, according to which practice is «the continuous reflection on utility» and theory "consists of being able to demonstrate and explain the things made with technical ability in terms of the principle of proportion» (Vitruvius Pollio, 15 BC).

Architecture will increasingly be forced to demonstrate how it represents an applied and intellectual activity of a targeted synthesis, of a complex system within which it is not only desirable, but indeed critical, for the cultural, social, environmental, climat- determinante, che riescano a interagire proattivamente le componenti culturali, sociali, ambientali, climatiche, energetiche, geografiche e tante altre, unitamente a quelle più proprie spaziali, funzionali, materiche che si esplicitano nel costruito per mezzo di fattori mutuati da ambiti limitrofi non solo endogeni alla disciplina architettonica.

Allinterno di una visione unitaria e parallela alla transcalarità che tale visione presuppone, la tecnologia dell'architettura, in qualità di disciplina spesso chiamata a svolgere un ruolo di collagene delle competenze, interviene come strumento di dominio all'interno della quale la scienza e la tecnica interpretano gli strumenti di traduzione delle esigenze intellettuali dell'uomo, esprimendo i principi aggiornati della cultura contemporanea.

All'interno del concetto di tradizione, desunto dal carattere evolutivo, forma, tecnica e produzione, nella loro "continuità" storica e tra loro non contrapposte, compongono i campi d'applicazione per mezzo dei quali, in parallelo, la ricerca procede al fine di garantire una conforme sintesi progettuale. La "tecnologia dell'architettura" e la "progettazione tecnologica" restituiscono la cifra anagrafica dellopera di architettura: una sorta di DNA da trasmettere alle future generazioni, anche in qualità di disciplina votata ad amalgamare i saperi provenienti da dimensioni altre della conoscenza.

Nell'esercizio progettuale confluiscono le categorie dell'urbanistica, della composizione, della tecnologia, della strutturisti$\mathrm{ca}$, dell'impiantistica, esito sempre più accentuato di sfumature multidisciplinari, alla ricerca dell'equilibrio delle parti: un assetto fondato sulla simultaneità e sulla logica eteronoma nello studio delle variabili, per mezzo di traduzioni, approcci e competenze quali espressione di variegate identità. «Gli architetti possono in- ic, energy-related, geographical and many other components involved in it to interact proactively, together with the more spatial, functional and material components that are made explicit in the final construction itself through factors borrowed from neighbouring field that are not endogenous to the discipline of architecture alone.

Within a unitary vision that exists parallel to the transcalarity that said vision presupposes, the technology of architecture - as a discipline often called upon to play the role of a collagen of skills, binding them together - acts as an instrument of domination within which science and technology interpret the tools for the translation of man's intellectual needs, expressing the most up-to-date principles of contemporary culture.

Within the concept of tradition - as inferred from its evolutionary charac- ter - form, technique and production, in their historical "continuity" and not placed in opposition to one other, make up the fields of application by which, in parallel, research proceeds with a view to ensuring a conforming overall design. The "technology of architecture" and "technological design" give the work of architecture its personal hallmark: a sort of DNA to be handed down to future generations, in part as a discipline dedicated to amalgamating the skills and expertise derived from other dimensions of knowledge.

In the exercise of design, the categories of urban planning, composition, technology, structure and systems engineering converge, the result increasingly accentuated by multidisciplinary nuances in search of a sense of balance between the parts: a setup founded upon simultaneity and heteronomous logic in the study of variables, by means of translations, approaches and skills as expressions of multifaceted identities. "Architects can influence society with their theories and works, but they are not capable of completing any such transformation on their own, and end up being the interpreters of an overbearing historical reality under which, if the strongest and most honest do not succumb, that therefore means that they alone represent the value of a component that is algebraically added to the others, all acting in the common field» (Rogers, 1951).

Construction, in this context, identifies the main element of the transmission of continuity in architecture, placing the "how" at the point of transition between past and future, rather than making it independent of any historical evolution. Architecture determines its path within a heteronomous prac- 
fluenzare la società con le proprie teorie e con le opere, ma non sono in grado di compiere la trasformazione da soli e finiscono con l'essere gli interpreti di una realtà storica prepotente dove, se i più forti e onesti non soccombono, questi rappresentano pertanto soli il valore di una componente che si somma algebricamente alle altre, agenti nel campo comune» (Rogers, 1951).

La costruzione, in tale contesto, identifica il principale elemento di trasmissione di continuità in architettura, ponendo il "come" nel punto di passaggio tra il passato e il futuro, non rendendolo indipendente da un'evoluzione storica. Larchitettura individua la sua strada all'interno di una pratica del costruire eteronoma, per mezzo dell'efficace distinzione tra la forza dei principi e dei codici propri della disciplina, consolidatisi per mezzo di sedimentate innovazioni, e dell'energia della sperimentazione in quanto tale. Larchitettura dovrà ricercare e affermare la propria identità, il suo essere disciplina al contempo scientifica e poetica, il suo essere rappresentato da armonie, codici e misure che la storia ci ha consegnato unitamente all'impellente dovere di elaborare una loro dovuta riattualizzazione. La complessità dell'ambito architettonico esprime, talvolta, forme di trattazione limitatamente chiuse in ambiti disciplinari ristretti oppure, per contrasto, eccessivamente sfrangiate e tendenti a un'ecletticità di tale vastità da impedirne una limpida perimetrazione culturale.

A dispetto del complesso fenomeno che caratterizza le trasformazioni che coinvolgono lo statuto del progetto e la figura del progettista, è impellente tentare di rinnovare l'interpretazione dellattività progettuale e dell'architettura quale sistema di coerenze più che somma di componenti. "Larchitettura contemporanea tende a produrre oggetti mentre la sua più concreta destinazione è quella di generare processi. Si tratta di una con-

tice of construction through an effective distinction between the strength of the principles and codes inherent to the discipline - long consolidated thanks to sedimented innovations and the energy of experimentation in its own right.

Architecture will have to seek out and affirm its own identity, its validity as a discipline that is at once scientific and poetic, its representation in the harmonies, codes and measures that history has handed down to us, along with the pressing duty of updating them in a way that is long overdue. The complexity of the architectural field occasionally expresses restricted forms of treatment bound to narrow disciplinary areas or, conversely, others that are excessively frayed, tending towards an eclecticism so vast that it prevents the tracing of any discernible cultural perimeter. traffazione densa di conseguenze perché confina l'architettura in una banda assai limitata del suo intero spettro; perciò, la isola, la espone ai rischi della subordinazione e delle manie di grandezza, la spinge verso l'irresponsabilità sociale e politica. La trasformazione dellambiente fisico passa attraverso una sequenza di eventi: la decisione di dar luogo a nuovo spazio organizzato, la rivelazione, il reperimento delle risorse necessarie, la definizione del sistema organizzativo, la definizione del sistema formale, le scelte tecnologiche, l'uso, la gestione, l'obsolescenza tecnica, il riuso, l'obsolescenza fisica. Questa concatenazione è l'intero spettro dell'architettura e ogni sua banda risente di quanto si verifica in tutte le altre.

Accade anche che la cadenza, l'ampiezza e l'intensità delle varie bande siano diverse secondo le circostanze e in relazione agli equilibri o agli squilibri dei contesti ai quali lo spettro corrisponde. Per di più ogni spettro non si esaurisce al termine della concatenazione dell'evento, perché i segni della sua esistenza - rovine e memoria - si proiettano su ulteriori eventi. Larchitettura è coinvolta con la totalità di questo complesso svolgimento: il progetto che esprime è lo spunto di un processo di lunga portata e di rilevanti conseguenze» (De Carlo, 1978).

Lera contemporanea propone la dialettica tra specializzazione, il coordinamento delle idee e delle azioni, la relazione tra attori, fasi, discipline: la pratica della cultura organizzativa del progetto circoscrive il proprio codice nella convivenza e reciproca valorizzazione tra saperi specialistici e disciplina di sintesi quale è l'architettura.

Nellorizzonte di una rinnovata economia globale, la dematerializzazione della pratica lavorativa ha implicato forti modifiche delle azioni produttive e delle relazioni sociali che coordinano il
In spite of the complex phenomenon that characterises the transformations that involve the status of the project and the figure of the architect themselves, it is a matter of urgency to attempt to renew the interpretation of the activity of design and architecture as a coherent system rather than a patchwork of components. «Contemporary architecture tends to produce objects, even though its most concrete purpose is to generate processes. This is a falsehood that is full of consequences because it confines architecture to a very limited band of its entire spectrum; in doing so, it isolates it, exposing it to the risks of subordination and delusions of grandeur, pushing it towards social and political irresponsibility. The transformation of the physical environment passes through a series of events: the decision to create a new organised space, detection, obtaining the necessary resources, defining the organisational system, defining the formal system, technological choices, use, management, technical obsolescence, reuse and - finally - physical obsolescence. This concatenation is the entire spectrum of architecture, and each link in the chain is affected by what happens in all the others.

It is also the case that the cadence, scope and intensity of the various bands can differ according to the circumstances and in relation to the balances or imbalances within the contexts to which the spectrum corresponds. Moreover, each spectrum does not conclude at the end of the chain of events, because the signs of its existence - ruins and memory - are projected onto subsequent events. Architecture is involved with the entirety of this complex development: the design that it expresses is merely the starting point for a far- reaching process with significant consequences» (De Carlo, 1978).

The contemporary era proposes the dialectic between specialisation, the coordination of ideas and actions, the relationship between actors, phases and disciplines: the practice of the organisational culture of design circumscribes its own code in the coexistence and reciprocal exploitation of specialised fields of knowledge and the discipline of synthesis that is architecture. With the revival of the global economy on the horizon, the dematerialisation of the working practice has entailed significant changes in the productive actions and social relationships that coordinate the process. Despite a growing need to implement skills and means of coordination between professional actors, disciplinary fields and sectors of activity, architectural design has become the emblem of the action 
processo. A dispetto di una crescente esigenza di implementare le competenze e i mezzi di coordinamento tra gli attori professionali, gli ambiti disciplinari e i settori di attività, il progetto di architettura diviene emblema dell'azione di sintesi. Una rappresentazione della società questa, che, sviluppata negli ultimi tre secoli, dal comparto delle scienze sociali in qualità di "macchina", "organismo" e "sistema", risulta attualmente definita dal concetto di "rete", ancor più dal "sistema di reti" nel quale la volontà relazionale colloca la persona in una molteplicità di sfere sociali.

L"eteronomia" dell'architettura, tra "ibridazione" e "contaminazione dei saperi", rappresenta non solo un dato oggettivo, bensì un concetto teso a fornire alla disciplina orizzonti nuovi e più ampi, in grado di porla nella condizione di affrontare con serenità, energia e coraggio le sfide che sempre più il contesto culturale, sociale, economico lanciano nel cuore della contemporaneità.

\section{REFERENCES}

Rogers, E.N. (1948), Il dramma dellarchitetto, testo tratto dalla lezione "El drama del arquitecto" tenuta presso la facoltà di Lettere e Filosofia della Universidad Mayor de San Marcos a Lima nel 1948, ora in: Esperienza dell'architettura (Ed. Molinari, L.), Skira, Milano, 1997, pp. 165-171.

De Carlo, G. (2001), in Franco Bunčuga, Conversazioni con Giancarlo De Carlo, Eleuthera, Milano, p. 106 e p. 115.

Siza, A. (2008), "Sulla pedagogia", Casabella n. 770.

Frampton, K. (2005), Tettonica e architettura. Poetica della forma architettonica nel XIX e XX secolo (a cura di M. De Benedetti), Skira, Milano.

Marco Vitruvio Pollione (1998), De Architectura (Ed. Bossalino, F.), Kappa, Roma, Libro I, pp. 36-37.

Rogers, E.N. (1951), "Evoluzione dell'architettura italiana contemporanea", in S. Maffioletti, (Ed. Rogers, E.N.), Architettura, Misura e grandezza dell'uomo, cit., pp. 430-433; versione in lingua italiana dell'articolo Id., The evolution of present day Italian Architecture in "Architect's Year Book IV", Londra.

De Carlo, G. (1978), “Editoriale”, Spazio e Società, n. 1, p. 6. of synthesis. This is a representation of society which, having developed over the last three centuries, from the division of social sciences that once defined it as a "machine", an "organism" and a "system", is now defined by the concept of the "network" or, more accurately, by that of the "system of networks", in which a person's desire to establish relationships places them within a multitude of social spheres. The "heteronomy" of architecture, between "hybridisation" and "contamination of knowledge", is to be seen not only an objective fact, but also, crucially, as a concept aimed at providing the discipline with new and broader horizons, capable of putting it in a position of serenity, energy and courage allowing it to tackle the challenges that the cultural, social and economic landscape is increasingly throwing at the heart of our contemporary world.

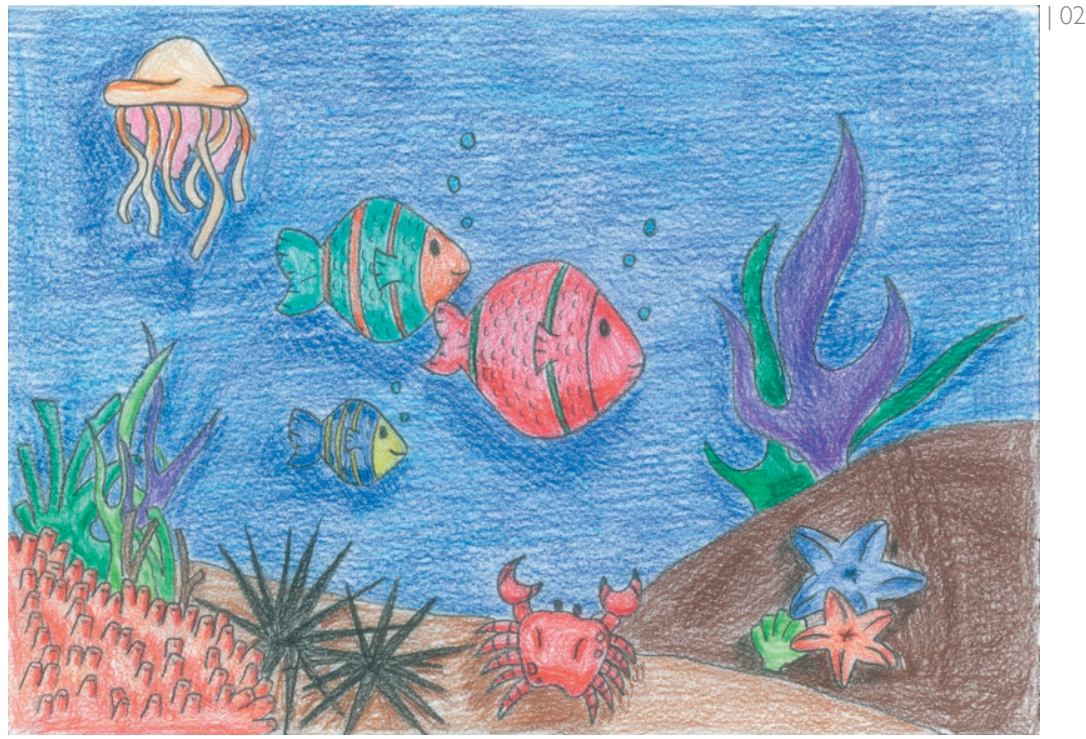

